\title{
EU-Parlamentet: Mere magt - mindre opbakning
}

Uffe Østergård

\section{Parlamentet er på trods af alt sit gode arbejde ikke interessant i befolkningernes øjne og har ikke for- mået at vinde afgørende legitimitet}

Den ene af Europa-Parlamentets to imposante bygninger i Bruxelles er opkaldt efter den italienske Europapolitiker Altiero Spinelli. Det er på mange måder vel fortjent og berettiget. Men navngivningen antyder nogle af de problemer der næsten fra begyndelsen har været med Parlamentets rolle i det europæiske samarbejde. Spinelli var nemlig en af de ledende føderalister og arbejdede konsekvent for overnationalt europæisk samarbejde under overskriften 'Europas Forenede Stater'.

Altiero Spinelli der levede fra 1907 til 1986, sluttede sig 17 år gammel til det kommunistiske parti for at kæmpe mod Mussolinis fascistiske styre i Italien. I 1927 blev han arresteret i Milano og i slutningen af 1930 'erne sammen med mange andre antifascister anbragt $\mathrm{i}$ isolation (på italiensk confino) på en af de Lipariske Øer, Ventotene, i havet mellem Napoli og Sicilien.
Dette fængsel kom til at fungere som universitet og politisk udklækningsanstalt for efterkrigstidens politiske elite i Italien, først og fremmest for det lille, men indflydelsesrige liberaldemokratiske Partito d'Azione der havde sin storhedstid fra 1943 til 1947. Hovedresultatet var affattelsen af det såkaldte Ventotene-manifest vinteren 1941-42, som skitserede en føderalistisk organisering af Europa efter sejren over nazismen og fascismen. Hovedforfatterne var Ernesto Rossi og Altiero Spinelli.

Ad forskellige omveje nåede dette manifest under kampene i Italien til Schweiz, hvor det blev omdøbt til 'Manifest for den europæiske modstandsbevægelse'. Dette dokument blev siden program for den føderalistiske Europabevægelse. Drivkraften bag det europæiske samarbejde, Jean Monnet, hyrede i 1952 Altiero Spinelli til at skrive udkastet til åbningstalen ved det første møde i den 
Høje Myndighed for Kul- og Stålunionen i august 1952. Monnet havde taget initiativet til dette samarbejde sammen med Robert Schuman i 1950, og han arbejdede for den eneste gang i sit liv som europæisk embedsmand som leder af den Høje Myndighed 1952-54. Normalt var hans fremgangsmåde at holde sig $\mathrm{i}$ baggrunden og arbejde via sine netværk.

Det var ikke Spinellis måde at arbejde på, og det kom hurtigt til et brud mellem de to stærke personligheder. Ifølge Spinelli havde Monnet nemlig ingen plan for, hvordan man skulle nå frem til en føderation.

Helt i overensstemmelse med sin normale fremgangsmåde mente Monnet at 'nogle få improviserede idéer' var tilstrækkeligt grundlag. Efter nogle få måneder i det lille Luxembourg vendte Spinelli tilbage til italiensk politik og kom først tilbage i europæisk politik i 1970, da han blev udnæunt til kommissær for industrielle anliggender.

\section{Demokratisk modydelse}

Her foretog han snart igen et overraskende skifte, idet han opgav kommissærposten og i stedet lod sig vælge til Europa-Parlamentet. Her var han afgørende for beslutningen om at indføre direkte valg i 1979, en beslutning der fik så skæbnesvangre følger i Danmark og andre lande, fordi midlerne fra de valgte medlemmer af Parlamentet siden har fi- nansieret bevægelserne mod EU uden om og i modsætning til de nationale politiske systemer. Spinelli fik i 1982 Parlamentet til at vedtage et første forfatningsudkast for Europa.

Det fik ingen umiddelbare følger, men det er nemt at forstå, hvorfor den føderalistiske italiener spiller så stor en rolle i Parlamentets selvforståelse i dag. Men det er et åbent spørgsmål om hans føderalistiske strategi har været til fordel for det europæiske samarbejde.

Indførelsen af direkte valg til Parlamentet i 1979 var ment som en 'demokratisk' modydelse for institutionaliseringen af møderne mellem statslederne i det Europæiske Råd i 1974. Det var tanken at Parlamentet skulle udgøre en 'folkelig' modvægt til regeringscheferne topmøder. Men sådan har det mildt sagt ikke fungeret.

Det er møder i det Europæiske Råd der har markeret de store spring fremad i samarbejdet som Maastricht 1991, Amsterdam 1997, København 2002 og senest Lissabon i 2007. Møderne har selvfølgelig også markeret lavpunkterne for EU, som da Silvio Berlusconi fortalte lumre vittigheder og lagde an på de andre regeringschefers overraskede hustruer eller mødet i Nice 2000, hvor et dårligt forberedt fransk formandskab forkludrede nyfordelingen af stemmevægtene i forbindelse med den store udvidelse mod øst og tabte alt på gulvet i nationalistisk iver efter at bevare lige så mange 
stemmer til Frankrig som til Tyskland.

Hensigten med 1970'ernes reorganisering af samarbejdet var at afbalancere øget intergovernmentalisme, repræsenteret ved det Europæiske Råd, med øget supranationalisme i form af et direkte valgt EuropaParlament. Siden 1979 har Parlamentet troligt fulgt op på Spinellis oprindelige strategi ved at kræve øget medbestemmelse ved hver traktatændring. Og trods beklagelser om manglende indflydelse har det haft stort held med at aftvinge de nationale regeringer øgede indrømmelser i bestandige forsøg på at rette op på det 'demokratiske underskud' i samarbejdet.

\section{Lav valgdeltagelse}

Problemet er imidlertid at valgdeltagelsen er faldet støt i takt med, at Parlamentets indflydelse er steget. Dette forhold sammen med de uløste problemer omkring lokaliseringen i Strasbourg, Luxembourg og Bruxelles, det svage fremmøde ved plenarmøderne - især den sidste dag - samt de høje lønninger og exorbitante rejseafregninger er det virkelige demokratiske problem i EU.

Problemer som næppe rettes op ved øget effektivitet i behandlingen af Kommissionens forslag, selv om der er sket overordentlig meget godt på dette område. Næppe heller ved at Parlamentet spiller med musklerne, som da det i 1999 truede
Santer-kommissionen til at gå af før tiden, eller da det afviste en italiener, Rocco Buttiglione, som medlem af Barrosos kommission.

Parlamentet er på trods af alt sit gode arbejde åbenbart ikke interessant i befolkningernes øjne og har ikke formået at vinde afgørende legitimitet.

Den faldende valgdeltagelse ved valgene til Europa-Parlamentet undrer mange professionelle iagttagere. Men den er egentlig en ganske logisk følge af det europæiske samarbejdes natur. Bortset fra den ensartethed der skabes af Domstolens afgørelser på de mange områder, som falder inden for Fællesskabets jurisdiktion, er EU fundamentalt et samarbejde mellem nationale stater.

\section{Øget national bevidsthed}

Man kan oven i købet iagttage en tendens til øget national bevidsthed i de lande, der ikke havde en stærkt udviklet national bevidsthed ved begyndelsen af samarbejdet. Et lille land som Luxembourg falder her i øjnene, men det er i virkeligheden en tendens der gælder i flertallet af EU's lande.

Kun i ekstremt nationale - for nu ikke at sige nationalistiske - lande som Danmark og United Kingdom er der ikke indtruffet en forøgelse af den nationale bevidsthed i kraft af samarbejdet. Men det er kun fordi det ikke muligt at have mere end 100 procents national bevidsthed. 
På den baggrund er det i grunden meget forståeligt, at befolkningerne ikke opfatter Parlamentet som en løsning på EU's demokratiske underskud, men som en del af det.

At det demokratiske underskud, lige såvel som 'europæiseringen' af administrationerne, reelt er fænomener i medlemslandene, ændrer ikke ved problemet, men øger det nærmest. I grunden ville det være logisk at vende tilbage til tiden før det direkte valg til Parlamentet, hvor det var sammensat af repræsentanter fra de nationale parlamenter. Det ville understrege samarbejdets karakter af et samarbejde mellem nationale stater.

Men det er ikke en farbar vej, og ikke blot fordi de store og flotte bygninger nu står der, i Bruxelles såvel som Strasbourg. Man kan aldrig gå tilbage til en forladt position. Reformtraktaten forsøger i stedet at inddrage de nationale parlamenter tidligere og mere direkte i lovgivningsprocessen. Det er velment, men strander formentlig på uvilje hos flertallet af parlamentarikere til at sætte sig ind i de enorme mængder af kompliceret regulering, der udgør kernen i det europæiske samarbejde.

Så alt tyder på at vi vil blive ved med at halte videre med et Parlament, der mødes i fine bygninger $\mathrm{i}$ Bruxelles og Strasbourg, mens administrationen sidder i Luxembourg, rejser hver måned frem og tilbage med tusindvis af kasser, og vælges af stadig værre vælgere.
Det problem afhjælpes næppe af, at motorvejen mellem Bruxelles og Strasbourg måske engang bliver repareret færdig. Og heller ikke af at man nu med over 50 års forsinkelse omsider har fået højhastighedstog til Strasbourg - i hvert fald fra den franske side. Det uafklarede forhold mellem intergovernmentalisme og føderalistisk supranationalisme vil leve videre i en usikker balance i det EU, vi stadig ikke kan karakterisere som andet end en UPO, et uidentificeret politisk objekt, som Jacques Delors så elegant udtrykte det.

\section{En ny helt?}

Men Parlamentet skulle måske finde sig en anden helt end Spinelli. Hvad med Jens Peter Bonde, den danske EU-skeptiker der har gjort politisk karriere på at kritisere EU, herunder Parlamentet? Han er jo indtil videre den dansker, der bedst har markeret sig som europæisk politiker, ganske vist som modstander af EU - eller i hvert fald som skeptiker. Men han opererer primært på den europæiske politiske scene, kun afbrudt af valgkampe hvert femte år og en folkeafstemning i ny og næ.

Netop Bondes modsigelsesfulde holdninger er på en paradoksal måde bedre i overensstemmelse med den reelle karakter af det europæiske samarbejde end den højtflyvende føderalistiske idealisme.

Bondes og andre ligesindedes ønsker om at beskytte den nationale 
suverænitet med alle midler har ført til samarbejde med ligesindede i andre lande. Det er der kommet mærkværdige, skiftende alliancer ud af mellem nordiske venstreorienterede og grønne, franske højreorienterede populister i Jean Marie le Pens Front National, excentriske britiske millionærer, katolske fundamentalister fra Polen og nu senest bulgarske og rumænske ekstremistiske nationalister.

Uanset hvor mærkværdige alliancerne kan forekomme anskuet i en traditionel højre-venstre optik, kan det ikke benægtes at modstanderne ofte opfører sig europæisk, samtidig med at de taler nationalt, mens til- hængerne taler europæisk og opfører sig nationalt.

Der er mange paradokser i europæisk samarbejde, men et af de største er at nationalstaterne reelt er blevet styrkede, samtidig med at vælgerne frygter, at deres nationale suverænitet er ved at forsvinde. Denne fejlagtige tro bliver ikke rigtigere af, at mange medlemmer af Parlamentet tror det samme.

Uffe Østergård, professor i europaisk og dansk historie, International Center for Business and Politics, CBS.

Artiklen indgår i en antologi, som Europa-Parlamentet udgiver til forairet. 